\title{
THE EXPERIMENTAL SUBSTANTIATION OF ADVISABILITY OF INTRODUCING AN ADJUVANT TO THE COMPOSITION OF THE IMMUNOBIOLOGICAL SOLUTION “CANDIDOCYDE”
}

\author{
M.V.Rybalkin, N.I.Filimonova
}

\author{
National University of Pharmacy
}

Key words: candidiasis; antigen; vaccine; immunity; adjuvant

\begin{abstract}
Candidal disease is growing around the world, and it is associated with a wide administration of antimicrobial, hormonal medicines and cytostatic drugs. To fight candidal infections the studies in developing vaccines against candidiasis are carried out actively in recent years in the world. At the premises of the National University of Pharmacy at the Biotechnology Department and the Department of Microbiology, Virology and Immunology the authors have developed a potential vaccine - the immunobiological solution "Candidocyde" based on the associated antigens of C. albicans and C. tropicalis fungi obtained by using ultrasound. For the purpose of the experimental substantiation of advisability of introducing an adjuvant to the composition of the immunobiological solution "Candidocyde" developed for preventing and treating candidal infections and based on the antigens of C. albicans and C. tropicalis fungi with the protein concentration of $3 \mathrm{mg} / \mathrm{ml}$ the samples of the solution "Candidocyde" separately with aluminium hydroxide and aluminium phosphate as adjuvants have been prepared and studied. The studies were performed in white mice with six animals in the group. The experimental samples in the volume of $0.2 \mathrm{ml}$ were injected intramuscularly twice with the interval of 14 days. According to the results of the research conducted it has been found that the immunobiological solution "Candidocyde" based on the antigens of C. albicans and C. tropicalis fungi with the protein concentration of $3 \mathrm{mg} / \mathrm{ml}$ and the adjuvant under study with two intramuscular injections in the volume of $0.2 \mathrm{ml}$ does not provide efficiency increase when preventing and treating candidal infections. Therefore, the adjuvant introduction into the composition of the immunobiological solution "Candidocyde" is impractical.
\end{abstract}

Candidal disease is growing around the world, and it is associated with a wide administration of antimicrobial, hormonal medicines and cytostatic drugs, as well as with increase of the spectrum of morbidity creating a positive background for development of candidiasis (diseases of the bloodforming organs, immune deficiency states, malignancies, radiation injury, HIV-infection, etc.). Often etiological factors of the disease are (in descending order): Candi$d a$ albicans, Candida tropicalis and others [2].

To fight candidal infections the studies are carried out actively in recent years both in the CIS countries, and in the countries of Europe and America $[8,10]$. It should be noted that currently no domestic vaccine is produced in Ukraine and no imported vaccines for prevention and treatment of candidiases have been registered. Therefore, development of a vaccine against candidal infection is the topical issue of modern pharmacy and medicine.

Taking into account the aforementioned, as well as the modern tendencies of combined subunit vaccines development $[3,6]$ it is expedient to create vaccines for preventing and treating candidal infections based on C. albicans and $C$. tropicalis fungi.

At the premises of the National University of Pharmacy at the Biotechnology Department and the Department of Microbiology, Virology and Immunology the authors have developed a potential vaccine - the immunobiological solution "Candidocyde" based on the associated antigens of $C$. albicans and $C$. tropicalis fungi obtained by using ultrasound.

Most vaccines cause a suboptimal immunological response. Intensification of immunogenic response to the vaccine introduction is possible due to addition of different substances or adjuvants to the vaccine, they can increase the vaccine activity, namely stimulate the antibody synthesis and inhibit the absorption of antigens [1].

Vaccines can be adsorbed on aluminium hydroxide, aluminium phosphate, calcium phosphate or other similar adsorbents prepared under special conditions that provide the appropriate physical state and adsorption properties $[1,5,9]$.

Stability of each adjuvant individually or in combination with antigen/antigens, especially for critical parameters, is determined in the process of development $[4,7]$. It should be noted that there are a lot of investigations concerning the harmful effects of these adjuvants on the human body [11-14]. That is why before introducing an adjuvant into the composition of vaccines it is necessary to verify that the effect obtained will be sufficiently significant.

The immunobiological solution "Candidocyde" developed contains the antigens of $C$. albicans fungi with the protein concentration of $3 \mathrm{mg} / \mathrm{ml}$ and C. tropicalis fungi with the protein concentration of $5 \mathrm{mg} / \mathrm{ml}$ in the ratio of $1: 1$, i.e. 
Table 1

Efficiency of the immunobiological solution "Candidocyde" with the adjuvants studied in prevention of candidiases, $n=6$

\begin{tabular}{|c|c|c|c|c|c|c|}
\hline \multirow{3}{*}{ Drug } & \multicolumn{7}{|c|}{ Experimental animals } \\
\cline { 2 - 7 } & 1 & 2 & 3 & 4 & 5 & 6 \\
\cline { 2 - 8 } & \multicolumn{7}{|c|}{ Results in 1 month } \\
\hline A & - & + & - & - & - & - \\
\hline B & + & - & - & + & + & - \\
\hline Control & - & - & + & + & - & - \\
\hline & & -7 & Results in 3 months & - \\
\hline A & - & + & - & - & + & - \\
\hline B & - & - & + & + & - & + \\
\hline Control & + & - & - & - & - & + \\
\hline
\end{tabular}

\section{Note:}

1) A - the immunobiological substance with aluminium hydroxide adjuvant; $B$ - the immunobiological substance with aluminium phosphate adjuvant;

2) «-»- absence of the disease, «+»-a mild form of the disease, «+ $+»-$ a moderate form of the disease, «+++» - an advanced form of the disease;

3) $n$ - is the number of animals in a group.

the total protein concentration is $4 \mathrm{mg} / \mathrm{ml}$. Taking into account that the immunobiological solution proposed in the given protein concentration possesses $100 \%$ activity when preventing and treating candidiases it is expedient to study the adjuvant introduction to the composition of the diluted immunobiological solution with the concentration of $3 \mathrm{mg} / \mathrm{ml}$.

The aim of this work is to substantiate experimentally advisability of introducing an adjuvant to the composition of the immunobiological solution based on the antigens of $C$. albicans and C. tropicalis fungi.

\section{Materials and Methods}

The immunobiological solution with the protein concentration of $3 \mathrm{mg} / \mathrm{ml}$ was researched with different adjuvants. The following adjuvants were studied: aluminium hydroxide and aluminium phosphate. The adjuvant content in one dose should not exceed $1.1 \mathrm{mg} / \mathrm{ml}$, i.e. $0.2 \mathrm{ml}$ of the immunobiological solution developed should contain $0.22 \mathrm{mg}$. The adjuvants under study were added separately into the immunobiological solution obtained. The complex of the immunobiological sub- stance with the adjuvant was placed in the thermostat and incubated at the temperature of $37 \pm 2^{\circ} \mathrm{C}$ while constant stirring at the rotation rate of $20 \mathrm{rpm}$ for 1 day. Then sorption of the adjuvant and antigen was checked. For this purpose the solution obtained was centrifuged at the rotation rate of $3000 \mathrm{rpm}$ for $15 \mathrm{~min}$. After that the precipitate was separated and the presence of the residual protein in the oversoda liquid was determined by the Lowry protein assay. In case of the protein absence the conclusion can be made that the complete sorption of the adjuvant and antigen occurred.

The immunobiological solution with different adjuvants was assessed as for its efficiency when preventing candidiases in the experiments in healthy two month white mice weighing 18-22 g. There were six animals in the control and experimental groups each; they were kept in the same conditions on a standard diet. Before the research the animals acclimatized themselves under experimental room conditions. Mice were injected intramuscularly $0.2 \mathrm{ml}$ of the immunobiological solution with the adjuvants studied in the upper part of the rear right paw. In
14 days $0.2 \mathrm{ml}$ of the immunobiological solution with the adjuvants studied was injected again in the upper part of the left rear paw. The animals of the control group were injected with the immunobiological solution without adjuvants. The experimental animals of one group were infected intraperitoneally in a month after the second injection, and in 3 months the second group was infected. For this purpose the suspension of Candida albicans fungi of CCM 335-867 strain in the amount of 20 mln. of cells and Candida tropicalis of ATTC 20336 strain in the amount of $60 \mathrm{mln}$. of cells in the volume of $1 \mathrm{ml}$ was used; the strains were introduced with an interval of 1 hour. In 14 days the animals were examined and the results were determined.

The test results were considered according to the number of various manifestations of the disease and were estimated by the following scheme: $(-)$ - the absence of manifestations of the disease; a mild form of the disease $(+)$ unkempt appearance, refusal to eat, the body weight loss, dysfunctions of the excretory organs; a moderate form of the disease $(++)-$ adynamia, unkempt appearance, refusal to eat, the body weight loss, contractures of the neck muscles, the lateral location of the body, dysfunctions of the excretory organs, when examining the mucous membranes of natural orifices the signs of pathological processes, plating of fungi with faeces were revealed; an advanced form of the disease $(+++)$ - adynamia, unkempt appearance, refusal to eat, the body weight loss, contractures of the neck muscles, paralysis of the limbs, convulsions, the lateral location of the body, dysfunctions of the excretory organs, during the autopsy when examining the mucous membranes of natural orifices, internal organs of the animals the signs of such pathological processes as microabscesses in the renal cortical layer, lungs, spleen, liver, etc., isolation of retrocultures of fungi from the animals' organs were 
revealed. This method was developed by the authors.

The therapeutic efficiency of the immunobiological solution with different adjuvants was investigated similarly to the method described above; the only difference was that the animals were infected with a contagium at first, and in 5 days two injections were made according to the scheme described. After that in 14 days the animals were examined and the results were determined.

\section{Results and Discussion}

According to the results of the research conducted it has been found that sorption of the adjuvants and antigen studied occurs completely; the negative test on protein detection by the Lowry protein assay indicates it after completion of the process.

The immunobiological solution "Candidocyde" with aluminium phosphate as an adjuvant in one month after repeated injection protected against infection $67 \%$ of animals, in 3 months $-67 \%$ of animals. The immunobiological solution with aluminium hydroxide as an adjuvant in one month after repeated injection of the drug protected against infection $83 \%$ of animals, in 3 months $-67 \%$ of animals. The experimental animals showed the signs of a mild form of the disease: unkempt appearance, refusal to eat, the body weight loss, dysfunctions of the excretory organs. The immunobiological solution without the adjuvants provides protection against infection $67 \%$ of mice in one and 3 months (Table 1).

The therapeutic efficiency of the immunobiological solution with all adjuvants was $83 \%$. The therapeutic effect started to manifest in 10-14 days after the first injection,

The therapeutic efficiency of the immunobiological solution "Candidocyde" with the adjuvants studied in candidiases, $n=6$

\begin{tabular}{|c|c|c|c|c|c|c|}
\hline \multirow{4}{*}{ Animals } & \multicolumn{6}{|c|}{ Drug } \\
\cline { 2 - 7 } & \multicolumn{7}{|c|}{ A } & \multicolumn{2}{c|}{ B } & \multicolumn{2}{c|}{ Control } \\
\cline { 2 - 7 } & $\begin{array}{c}\text { After } \\
\text { infection }\end{array}$ & $\begin{array}{c}\text { After the } \\
\text { second } \\
\text { injection }\end{array}$ & $\begin{array}{c}\text { After } \\
\text { infection }\end{array}$ & $\begin{array}{c}\text { After the } \\
\text { second } \\
\text { injection }\end{array}$ & $\begin{array}{c}\text { After } \\
\text { infection }\end{array}$ & $\begin{array}{c}\text { After the } \\
\text { second } \\
\text { injection }\end{array}$ \\
\hline 1 & ++ & - & + & - & + & - \\
\hline 2 & + & + & ++ & - & ++ & + \\
\hline 3 & ++ & - & ++ & - & + & - \\
\hline 4 & + & - & ++ & + & ++ & - \\
\hline 5 & ++ & - & + & - & + & - \\
\hline 6 & ++ & - & ++ & - & ++ & - \\
\hline
\end{tabular}

Note:

1) A - the immunobiological substance with aluminium hydroxide adjuvant; $B$ - the immunobiological substance with aluminium phosphate adjuvant;

2) «-» - absence of the disease, «+»-a mild form of the disease, «+ +» - a moderate form of the disease, «+++»- an advanced form of the disease;

3) $n-$ is the number of animals in a group.

and in 10-14 days after the repeated injection there was a complete recovery of the animals. The experimental animals showed the signs of a mild form of the disease: unkempt appearance, refusal to eat, the body weight loss, dysfunctions of the excretory organs. The immunobiological solution without adjuvants gives the therapeutic effect in $83 \%$ of mice (Table 2).

Taking into account that addition of adjuvants to the composition of the immunobiological solution "Candidocyde" has not provided efficiency increase when preventing and treating candidal infections, as well as considering the fact that the immunobiological solution without adjuvants contains fewer excipients, it is more expedient not to use adjuvants. This decision is also based on a large number of data about the perni- cious influence of adjuvants on the human body. It should be also noted that during storage adsorbed vaccines form a precipitate at the bottom of the container, and it negatively affects the further use of the immunobiological drug.

\section{CONCLUSIONS}

According to the results of the research conducted it has been found that the immunobiological solution "Candidocyde" based on the antigens of C. albicans and C. tropicalis fungi with the protein concentration of $3 \mathrm{mg} / \mathrm{ml}$ and the adjuvant under study with two intramuscular injections in the volume of $0.2 \mathrm{ml}$ does not provide efficiency increase when preventing and treating candidal infections. Therefore, the adjuvant introduction into the composition of the immunobiological solution "Candidocyde" is impractical.

\section{REFERENCES}

1. Атауллаханов Р.И., Хаитов Р.М. // Иммунол. - 2011. - Т. 32, №1. - С. 37-45.

2. Голубка О.В. // Annals of Mechnikov Institute. - 2011. - №2. - C. 51-59.

3. Жукова Н.В., Кривошеева И.М. // Кримський терапевт. журн. - 2013. - №2. - С. 99-104.

4. Краснопольский Ю.М., Борщевская М.И. Фармацевтическая биотехнология. Технология производства иммунобиологических препаратов. - Х.: НТУ «ХПИ», 2009. - 352 с. 
5. Перцев I.М., Дмитрієвський Д.І., Рибачук В.Д. та ін. Допоміжні речовини в технології ліків: вплив на технологічні, споживчі, економічні характеристики і терапевтичну ефективність: Навч. посіб. / За ред. І.М.Перцева. - Х.: Золоті сторінки, 2010. - 598 с.

6. Петров Р.В., Хаитов Р.М. Иммуногены и вакцины нового поколения. - М.: ГЭОСТАР-Медицина, 2011. $-608 \mathrm{c}$.

7. Чуєшов B.I., Гладух Є.В., Сайко І.В. та ін. Технологія ліків промислового виробництва: Підруч. для студ. вищ. навч. закл.: у 2-х ч. - 2-е вид., перероб. і доп. - Х.: НФаУ; Оригінал, 2012. - Ч. 1. - 694 с.

8. Cassone A. // Nature Rev. Microbiol. - 2013. - Vol. 11. - P. 884-891.

9. Exley C., Siesjo P., Eriksson H. // Trends Immunol. - 2010. - Vol. 4, №23. - P. 103-109.

10. Grover A., Bhandari B.S., Rai N., Lakhera P.C. // Biotechnol. Intern. - 2010. - Vol. 3, №1 . - P. 4-17.

11. Shaw C.A., Petrik M.S. // J. Inorg. Biochem. - 2009. - Vol. 11, №103. - P. 1555-1562.

12. Shoenfeld Y., Agmon-Levin N. // J. Autoimmunol. - 2011. - Vol. 1, №36. - P. 4-8.

13. Tomljenovic L. // J. Alzheimers. Dis. - 2011. - Vol. 4, №23. - P. 567-598.

14. Tomljenovic L., Shaw C.A. // Current Med. Chemistry. - 2011. - №18. - P. 2630-2637.

\title{
ЕКСПЕРИМЕНТАЛЬНЕ ОБГРУНТУВАННЯ ДОЦІЛЬНОСТІ ВВЕДЕННЯ АД'ЮВАНТУ ДО СКЛАДУ ІМУНОБІОЛОГІЧНОГО РОЗЧИНУ “КАНДИДОЦИД"
}

М.В.Рибалкін, Н.І.Філімонова

Національний фармацевтичний університет

Ключові слова: кандидамікоз; антиген; вакцина; імунітет; ад'ювант

Захворюваність на кандидоз зростає у всьому світі, і це пов'язують з широким використанням антибактеріальних препаратів, гормональних засобів, цитостатиків. Для боротьби з кандидозною інфекцією останніми роками активно ведуться дослідження в усьому світі з розробки вакцин проти кандидамікозів. Ученими на базі Національного фармацевтичного університету на кафедрі біотехнології та мікробіології, вірусології та імунології було розроблено потенційну вакцину - імунобіологічний розчин «Кандидоцид» на основі поєднаних антигенів грибів C. albicans ma C. tropicalis, одержаних при використанні ультразвуку. 3 метою експериментального обгрунтування доцільності введення ад'юванту до складу розробленого імунобіологічного розчину «Кандидоцид» для попередження та лікування кандидозної інфекції на основі антигенів грибів C. albicans ma C. tropicalis з концентрацією білка 3 мг/мл були виготовлені і досліджені зразки розчину «Кандидоцид» окремо з ад'ювантами гідроксидом алюмінію та фосфатом алюмінію. Дослідження проводили на білих мишах по 6 тварин у групі. Дослідні зразки вводили двократно внутрішньом'язово по 0,2 мл з інтервалом 14 діб. У результаті проведених досліджень встановлено, що імунобіологічний розчин «Кандидоцид» на основі антигенів грибів C. albicans ma C. tropicalis 3 концентрацією білка 3 мг/мл з досліджуваними ад'ювантами при двократному внутрішньом'язовому введенні по 0,2 мл не забезпечує підвищення ефективності при попередженні та лікуванні кандидозної інфекції. Тому введення ад'юванту до складу імунобіологічного розчину «Кандидоцид» недоцільне.

\section{ЭКСПЕРИМЕНТАЛЬНОЕ ОБОСНОВАНИЕ ЦЕЛЕСООБРАЗНОСТИ ВВЕДЕНИЯ АДЪЮВАНТА В СОСТАВ ИММУНОБИОЛОГИЧЕСКОГО РАСТВОРА «КАНДИДОЦИД»}

\section{Н.В.Рыбалкин, Н.И.Филимонова}

\section{Национальный фармацевтический университет}

Ключевые слова: кандидамикоз; антиген; вакцина; иммунитет; адъювант

\begin{abstract}
Показатель заболевания кандидозом растет по всему миру, и это связывают с широким использованием антибактериальных препаратов, гормональных средств, цитостатиков. Для борьбы с кандидозной инфекцией в последние годы активно ведутся исследования во всем мире по разработке вакцин против кандидамикозов. Учеными на базе Национального фармащевтического университета на кафедре биотехнологии и микробиологии, вирусологии и иммунологии была разработана потенциальная вакцина - иммунобиологический раствор «Кандидоцид» на основе объединенных антигенов грибов C. albicans и C. tropicalis, полученных при использовании ультразвука. С целью экспериментального обоснования целесообразности введения адъюванта в состав разработанного иммунобиологического раствора «Кандидоцид» для предупреждения и лечения кандидозной инфекции на основе антигенов грибов C. albicans и C. tropicalis с концентрацией белка 3 мг/мл были изготовлены и исследованы образцы раствора «Кандидоцид» отдельно с адъювантами гидроксидом алюминия и фосфатом алюминия. Исследования проводились на белых мышах по 6 животных в группе. Опытные образцы вводили двукратно внутримышечно по 0,2 мл с интервалом 14 дней. В результате проведенных исследований установлено, что иммунобиологический раствор «Кандидоцид» на основе антигенов грибов C. albicans и C. tropicalis с концентрацией белка 3 мг/мл с исследуемыми адъювантами при двукратном внутримышечном введении по 0,2 мл не обеспечивает повышение эффективности при предупреждении и лечении кандидозной инфекции. Поэтому введение адъюванта в состав иммунобиологического раствора «Кандидоцид» нецелесообразно.
\end{abstract}

